\title{
Preface - Engaging Local Wisdom in the New Millenium
}

\author{
Nurul Farhana Low Abdullah ${ }^{11}$ \\ ${ }^{1}$ School of Humanities, Universiti Sains Malaysia
}

The United Nations Educational, Scientific and Cultural Organisation (UNESCO) describes Local knowledge as 'the understandings, skills and philosophies developed by societies with long histories of interaction with their natural surroundings'. In rural and indigenous communities, local knowledge 'informs decision making about fundamental aspects of day to day life' and forms the basis for the various facets of culture in the community including language, social interactions, ritual and spirituality, as well as practices related to use of resources. [1]

This body of wisdom has developed over time and continues to develop. The practical aspects of local knowledge are highlighted by the UN Food and Agriculture Organisation through its definition of local knowledge: '...the entire system of concepts, beliefs and perceptions that people hold about the world around them. This includes the way people observe and measure their surroundings, how they solve problems and validate new information. It includes the processes whereby knowledge is generated, stored, applied and transmitted to others'. [2]

The fact of these formulations being endorsed by a global organisation like the UN validates and necessitates further study into Local Knowledge, its universal relevance and multi-faceted applications across disciplines and locations. Thus, in the spirit of inclusiveness and inquiry. the Local Knowledge Study Group of Universiti Sains Malaysia (USM) first embarked on its quest to foreground the study of this transdisciplinary form of knowledge at regional level to serve as 'a foundation for locally-appropriate sustainable development' (as succinctly noted by UNESCO) with its inaugural Regional Conference on Local Knowledge in Langkawi, Kedah in 2011. Seven annual conferences and 40 edited books later, the organisers of the (rebranded) International Conference on Local Knowledge (ICLK) 2017 are seeking to disseminate contemporary research findings, built around the theme of "Engaging Local Wisdom in the New Millenium" to a global audience through its first publication of indexed proceedings in SHS Web of Conferences.

The seventh instalment of ICLK was organised by USM on 8-9 May 2017 in collaboration with the Johor State Government through its cultural arm, the Yayasan Warisan Johor and supported by Dewan Bahasa dan Pustaka where 90 papers were presented by local and international participants. The papers in these Proceedings represent a selection of the latest transdisciplinary research that engages with various forms of Local Wisdom in their framework of analysis. The articles have been divided into the following areas, according to thematic focus: Architecture and Conservation, Arts and Crafts, Ecology and Ecosystems, Governance and Policy, Health and Healing, History and Community and finally, Language, Literature and Media.

As guest editor of this volume of selected conference papers, I would like to take this opportunity to thank the members of the Scientific Committee, reviewers and contributors for their co-operation and commitment throughout the process of producing this collection of papers. I would also like to record sincere thanks to all parties who participated in the organisation of the $7^{\text {th }}$ ICLK for making the conference a success.

\section{GUEST EDITOR}

Nurul Farhana Low Abdullah, Universiti Sains Malaysia

\footnotetext{
${ }^{1}$ Corresponding author: nflow@usm.my
} 


\section{EDITORIAL ASSISTANT}

Nur Yuhainis Amirnuddin, Local Knowledge Group, Universiti Sains Malaysia

\section{SCIENTIFIC COMMITTEE}

Professor Dato' Dr. Omar Osman Vice-Chancellor of DRB Hicom University of Automative Malaysia Professor Dr. Ir. M. Salleh S. Ali Lecturer, Universitas Hasanudin, Makassar, Indonesia

Prof. Dr. Badaruddin Mohamed Lecturer, School of Housing, Building \& Planning , Universiti Sains Malaysia

Associate Professor Dr. Syed Muhd Khairuddin Aljuneid Lecturer, National University of Singapore

Professor Masshor Mansor Lecturer, Universiti Sains Malaysia

Dr Hasni bin Arsad, Lecturer Universiti Sains Malaysia

Mr. Iskandar Al-Bakri (Malaysian Author), Advocate \& Solicitor at the Iskandar Al-Bakri \& Associates

Prof. Dr. Azizi Bahauddin Lecturer, School of Housing,Building \& Planning, Universiti Sains Malaysia

Prof. Dr. Supyan Hussin Director, Institute of the Malay World and Civilization, Universiti Kebangsaan Malaysia

Prof. Dr. Wan Izatul Asma Wan Talaat Lecturer, Institut Oceanography \& Environment, Universiti Malaysia Terengganu

Assoc. Prof. Dr. Salasiah Che Lah, Deputy Dean Research, Postgraduate \& Network, School of Humanities, Universiti Sains Malaysia

Assoc. Prof. Dr. Norizan Esa Lecturer, School of Educational Studies, Universiti Sains Malaysia

Assoc. Prof. Dr. Zuraidah Mohd Yusoff Lecturer, School of Pharmaceutical Sciences, Universiti Sains Malaysia

Assoc. Prof. Dr. Noorma Wati Haron Lecturer, Institute of Biological Sciences, Faculty of Science

University of Malaya

Assoc Prof. Dr. Tarmiji Masron Lecturer, Faculty of Social Science, Universiti Malaysia Sarawak

Assoc. Prof. Dr. Mardiana Idayu Ahmad Lecturer, School of Industrial Technology, Universiti Sains Malaysia

Assoc. Prof. Dr. Mohd Kipli B. Abdul Rahman, Faculty of Music \& Performing Arts, Sultan Idris Education University,

Dr. Ku Boon Dar Lecturer, School of Distance Education, Universiti Sains Malaysia

Dr. Zikri Muhammad Lecturer, School of Social and Economic Development, Universiti Malaysia Terengganu

Dr. A. S. Hardy Shafii, Deputy Dean Research, Postgraduate \& Network, School of The Arts

Dr. Mohd Asyiek Mat Desa Lecturer, School of The Arts, Universiti Sains Malaysia

Dr. Mumtaz Begum Bt. Pv Aboo Backer Lecturer, School of The Arts, Universiti Sains Malaysia

Dr. Darlina Md. Naim Lecturer, School of Biological Sciences, Universiti Sains Malaysia

Dr. Nurul Farhana Low Abdullah Lecturer, School of Humanities, Universiti Sains Malaysia

Ms. Norfarizah Mohd Bakhir Lecturer , School of The Arts, Universiti Sains Malaysia

\section{REFERENCES}

1. UNESCO - Natural Sciences - Priority Areas: http://www.unesco.org/new/en/natural-sciences/priorityareas/links/related-information/what-is-local-and-indigenous-knowledge/

2. Food and Agriculture Organization of the United Nations - Fact Sheet: http://www.fao.org/docrep/007/y5610e/y5610e01.htm\#bm1 